https://doi.org/10.52326/jes.utm.2021.28(4).14

CZU 691.32:620.193
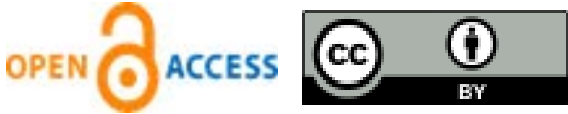

\title{
STRUCTURAL PARAMETERS OF CONCRETE CORROSION RESISTANCE
}

\author{
Albina Eletchih*, ORCID: 0000-0002-6960-3104 \\ Technical University of Moldova, 168 Stefan cel Mare Blvd., Chisinau, Republic of Moldova \\ ${ }^{*}$ Corresponding author: Albina Eletchih, albina.eletchih@dmmc.utm.md
}

Received: 09. 10. 2021

Accepted: 11. 12. 2021

\begin{abstract}
This article describes the problem of corrosion of concrete at the enterprises of the wine and fruit and vegetable industry in Moldova, the kind of organic acids that destroy concrete are considered. Such a specific type of chemical corrosion as leaching is also considered. The reaction of the influence of malic acid on concrete is reflected, as a result of which readily soluble calcium malic acid is formed. The structural parameter of corrosion resistance to chemical corrosion has been studied. The formula for the corrosion resistance of concrete is derived and explained. The structural parameter of resistance to chemical corrosion is investigated on various types of concrete. The formula for coefficient resistance of concrete to chemical corrosion is derived. Also, two dependencies are displayed: Dependence of the coefficient of resistance of concrete to chemical corrosion on the volume of cement stone; Dependence of the coefficient of concrete resistance to leaching corrosion on the structural parameter.
\end{abstract}

Keywords: corrosion destruction of concrete, calcium hydroxide, coefficient of resistance, parameter of concrete corrosion resistance, volume of the modified cement stone, structural parameter of leaching corrosion, the porosity of the 1st and 2nd groups.

Abstract. Acest articol descrie problema coroziunii betonului la întreprinderile din industria vinului, fructelor și legumelor din Moldova. Sunt luate în considerare, ce fel de acizi organici distrug betonul. Un astfel de tip specific de coroziune chimică precum levigarea este, de asemenea, luat în considerare. Se reflectă reacția influenței acidului malic asupra betonului, în urma căreia se formează acid malic de calciu ușor solubil. A fost studiat parametrul structural al rezistenței la coroziune la chimică. Este derivată și explicată formula pentru rezistența la coroziune a betonului. Parametrul structural de rezistență la coroziune chimică este investigat pe diferite tipuri de beton. Este derivată formula pentru coeficientul de rezistență al betonului la coroziune chimică. De asemenea, sunt afișate două dependențe: Dependența coeficientului de rezistență al betonului la coroziune chimică de volumul pietrei de ciment; Dependența coeficientului de rezistență a betonului la coroziune prin levigare de parametrul structural.

Cuvinte cheie: distrugerea betonului la coroziune, hidroxid de calciu, coeficientul de rezistență, parametrul de rezistență la coroziune a betonului, volumul pietrei de ciment modificate, parametrul structural al coroziunii prin levigare, porozitatea grupelor 1 și 2. 


\section{Introduction}

At the enterprises of the wine and fruit and vegetable industry in Moldova, a significant part of the reinforced concrete structures of buildings and structures, as well as technological equipment (floors, columns and walls, reinforced concrete bunkers for receiving fruit and vegetable raw materials, tanks for storing processed fruit and vegetable products, etc.) are practically in operation. under the constant influence of aggressive environments.

The destructive effect on concrete is exerted, first of all, by organic acids (lactic, malic, acetic, citric, tartaric) and others. These substances react with calcium hydroxide $\mathrm{Ca}(\mathrm{OH})_{2}$, forming soluble calcium salts, which dissolve and pass into food products.

To a certain extent, the destruction of concrete also occurs under the influence of various microorganisms contained in the products of processing of fruits and vegetables.

In the problem of improving the quality of concrete at the enterprises of the fruit and vegetable industry, resistance to chemical corrosion will always occupy a special place, since it is this that has a decisive influence on the design service life of the structure.

The experience of the construction and operation of wine-making and fruit-growing enterprises in Moldova shows that even in an uncontaminated air-humid environment, prefabricated reinforced concrete structures can be damaged due to corrosion of the reinforcement. In the presence of acid gases (for example, in factories for the production of juices, wines, where anhydride is used), the damage to reinforced concrete is even more significant.

Such a specific type of chemical corrosion as leaching is also dangerous. Cases are known when concrete wear due to leaching reached 5-10 cm. Of great importance, in particular, is the provision of the required resistance to leaching for cooling towers used for cooling various kinds of technological equipment continuously washed with soft water.

At the same time, the organization of monitoring the resistance of concrete to chemical corrosion at factories and construction sites does not meet modern requirements. Often, the operations of monitoring corrosion resistance are reduced to approximate estimates based on data on the quality of raw materials and the composition of concrete.

Experimental assessment of the corrosion resistance of concrete in factories is practically not carried out. For example, in the construction laboratories of Moldova there is not a single installation for testing concrete for resistance to chemical corrosion.

The reason for this is the laboriousness and duration of standard methods for testing the resistance of concrete to chemical corrosion, which makes them ineffective under factory conditions. Practice has shown the need to develop methods for predicting and accelerating the assessment of corrosion resistance of various types of concretes used at the enterprises of wine and fruit and vegetable production.

Theoretical and technological prerequisites give reason to believe that all these conditions should be met by methods for assessing the corrosion resistance of concrete by the parameters of their structure.

\section{Features of the development of corrosion processes in wine and fruit and vegetable enterprises}

During operation, concrete and reinforced concrete structures are exposed to various liquid, solid and gaseous aggressive media, which, according to the existing classification $[1,2]$, are conventionally combined into three groups: physical, physicochemical and chemical. 
Physical corrosion of concrete occurs as a result of its alternating drying and wetting, which is accompanied by deformations of shrinkage and swelling of the material, deposition of soluble salts in the pores of the cement stone, alternating freezing and thawing, and other temperature effects.

Physicochemical corrosion of concrete occurs due to leaching of the constituents of the cement stone and as a result of osmotic and concentration phenomena.

Chemical corrosion of concrete is caused by the interaction of the constituent parts of the cement stone with acids, alkalis, salt solutions, various organic compounds, as well as all corrosive gases.

The most common types of processed fruit and vegetable products are canned vegetables $(\mathrm{pH}=3.7 \ldots 4.4)$ and vegetable marinades $(\mathrm{pH}<3.7)$.

Another widespread ecological product is juices, which are characterized by ecological data containing acids and sugars.

Taking into account the $\mathrm{pH}$ value of these products, the content of organic acids and sugar in them, it follows that they cause, first of all, chemical corrosion of concrete.

Organic acids contained in these products, upon contact with cement stone, interact primarily with $\mathrm{Ca}(\mathrm{OH})_{2}$, and then with hydrosilicates and calcium hydroaluminates to form readily soluble calcium salts that do not have astringent properties [3].

The rate of corrosion destruction of concrete largely depends on the structure of the formed layer of corrosion products, their degree of solubility, the access of an aggressive medium, its reactivity and the rate of its exchange at the concrete surface $[4,5]$.

The durability of reinforced concrete tanks operated in the food industry depends on the degree of aggressiveness of the environment in relation to concrete.

Food products differ in their chemical composition and, accordingly, their aggressiveness differs.

Fruit and berry juices are the most aggressive. Compared to grape juice, natural fruit and berry juices contain little sugar and a lot of acids, of which malic acid is the most aggressive [4]. The predominance of malic acid makes the juices more aggressive towards concrete, and upon contact with it, readily soluble malic acid calcium is formed [3] according to the following reaction" Eq.(1)".

$$
\mathrm{C}_{4} \mathrm{H}_{6} \mathrm{O}_{5}+\mathrm{Ca}(\mathrm{OH})_{2}=\mathrm{C}_{4} \mathrm{H}_{4} \mathrm{O}_{5} \mathrm{Ca}+2 \mathrm{H}_{2} \mathrm{O}
$$

The formed calcium malate does not possess astringent properties, which leads to the destruction of the inner surface of the tanks. Tartaric acid of grape juice $[6,7]$ reacts with $\mathrm{Ca}(\mathrm{OH})_{2}$ of concrete cement stone, forming calcium tartrate. The formed calcium tartrate is slightly soluble and at the beginning of the operation of the tanks serves as a protective coating, but under the action of tartaric acid it turns into acidic calcium tartrate, which dissolves easily. Therefore, wines with a relatively high content of tartaric acid can dissolve the "protective layer" of calcium tartrate, and when the layer of tartar is 2-3 mm thick, harmful microflora begins to develop in it, which negatively affects the quality of the wine, and with a thickness of 4 - $5 \mathrm{~mm}$ on cracks form, and the wine, easily seeping, causes further corrosion of the concrete.

The destruction of the inner surface of the tanks degrades the quality of the wine, products of concrete corrosion and an unpleasant earthy aftertaste appear in it. The tartar is removed periodically with a hammer and scraper, which is quite difficult. In this case, the inner surface of the tanks becomes rough, which makes it difficult to rinse them. Lactic acid 
contained in pickles and products, beer and wort [8], products of dairy and cheese factories [9], when interacting with $\mathrm{Ca}(\mathrm{OH})_{2}$ of cement stone of concrete, forms lactate of lactic acid calcium. Other reactions of interaction of $\mathrm{Ca}(\mathrm{OH})_{2}$ with organic acids contained in processed fruit and vegetable products proceed similarly.

Citric acid contained in juices and beer, upon interaction with $\mathrm{Ca}(\mathrm{OH})_{2}$, forms tricalcium citrate [8]. Under the action of acetic acid, which is used in the technological processes of canneries and contained in beer [8], concrete corrosion occurs in several stages with the formation of final products - silicic acid gel, calcium acetate and aluminum hydroxide gel.

Salts of these acids increase in volume during crystallization and destroy concrete [9, 10]. Sugar, carbon dioxide, alcohol, glycerin, which are part of the wort $(\mathrm{pH}=5.5 \ldots 6.0)$ and beer $\left(\mathrm{pH}=4.5\right.$... 5.6), form upon interaction with $\mathrm{Ca}(\mathrm{OH})_{2}$ cement stone, readily soluble sugars, bicarbonates, alcoholate and calcium glycerate, which contribute to the destruction of building structures.

In confectionery factories, the most aggressive effect on building structures is provided by media containing glucosides. They penetrate deep into the concrete, causing corrosion of the reinforcement and destruction of concrete [11].

Acceleration of corrosion of reinforced concrete tanks when exposed to food environments is also caused by some salts, such as $\mathrm{NaCl}$, for example, contained in fermented foods and pickles.

At meat processing and canning factories, $\mathrm{NaCl}$ solutions are used for cleaning premises. The same salt is sometimes sprinkled on floors. When concrete is impregnated with a $\mathrm{NaCl}$ solution, its physical corrosion occurs [12]. An external sign of this type of corrosion is the appearance of cracks in concrete and reinforced concrete structures.

In this case, the cause of corrosion is crystallization pressure, which reaches $0.27 \mathrm{MPa}$ and is caused by the deposition of salt in the voids and pores of concrete during its periodic moistening and drying [3].

In addition, ions such as $\mathrm{Na}+, \mathrm{Cl}$ - increase the solubility of $\mathrm{Ca}(\mathrm{OH})_{2}$, which is the main regulator in the cement stone - water system. The amount of $\mathrm{Ca}(\mathrm{OH})_{2}$ in Portland cement stone after one month of hardening is $9-11 \%$, and after 3 months it reaches $15 \%$ of the cement mass [13].

Having the highest solubility, $\mathrm{Ca}(\mathrm{OH})_{2}$ gradually leaches out when water acts on concrete, and free $\mathrm{Ca}(\mathrm{OH})_{2}$ passes into the solution [1 - 3].

With the development of chemical corrosion in the structural elements of cement stone and other porous materials, mainly tensile stresses arise, as a result of which, under the action of external forces, its tensile strength decreases. Therefore, concrete with a lower tensile strength is less resistant to the development of chemical corrosion and its destruction occurs faster.

Thus, the destruction of cement stone and concrete under the influence of technological solutions of food production occurs mainly as a result of processes caused by chemical corrosion.

\section{Structural parameter of concrete resistance to chemical corrosion (second type of corrosion)}

The solubility of cement hydration products in water and their chemical activity predetermine the possibility of a special type of corrosion - corrosion of the 2nd kind (according to V.M. Moskvin) [14]. This type of corrosion received its characteristic name due 
to the fact that the most water-soluble and chemically active compound in cement stone is alkali - calcium hydroxide. The danger of corrosion of the 2 nd kind in food enterprises has been known since the beginning of the last century [15]. Years of experience in the operation of various concrete structures have shown that this type of corrosion must be reckoned with. For example, there are known cases when the wear of concrete reached $5 . .10 \mathrm{~cm}$ [16].

In essence, chemical corrosion has a certain specificity that must be taken into account when developing the corresponding structural parameter.

In particular, data on the solubility of cement stone components in water and on the kinetics of dissolution processes are very important.

The highest solubility and chemical activity, as already noted, among the compounds of cement stone is possessed by calcium hydroxide (portlandite). In addition, there is a lot of it in the cement stone - already after 3 months up to $15 \%$ of the cement mass [17]. The solubility of hydroxide in distilled water is quite high $-1.18 \mathrm{~g} / \mathrm{l}$ in terms of $\mathrm{CaO}$, in principle, the formation of supersaturated solutions with a $\mathrm{CaO}$ concentration of up to $1.9 \mathrm{~g} / \mathrm{l}$ is possible. If conditions are created for the gradual decomposition of calcium hydroxide from the cement stone, then at the beginning free calcium hydroxide will pass into the solution, but when a significant part of it is removed, the hydrolysis of hydrosilicates and hydroaluminates of calcium will begin with the release of calcium hydroxide [14].

The least stable of the hydrosilicates is dicalcium hydrosilicate. At a hydroxide concentration of less than $0.05 \mathrm{~g} / \mathrm{l}(\mathrm{pH}=11)$, hydrosilicates completely dissolve, and only $\mathrm{Si}(\mathrm{OH})_{4}$ gel remains in the solid phase.

The lower limit of the stable state of tricalcium hydroaluminate is the $\mathrm{CaO}$ content in the solution of $0.315 \mathrm{~g} / \mathrm{L}$ [18]. All this information about the chemical stability of cement stone compounds is necessary to determine the structural parameter of resistance to leaching, in particular, when calculating the volume of "chemically modified" (according to F.M. Ivanov) during corrosion of cement stone "Figure 1".

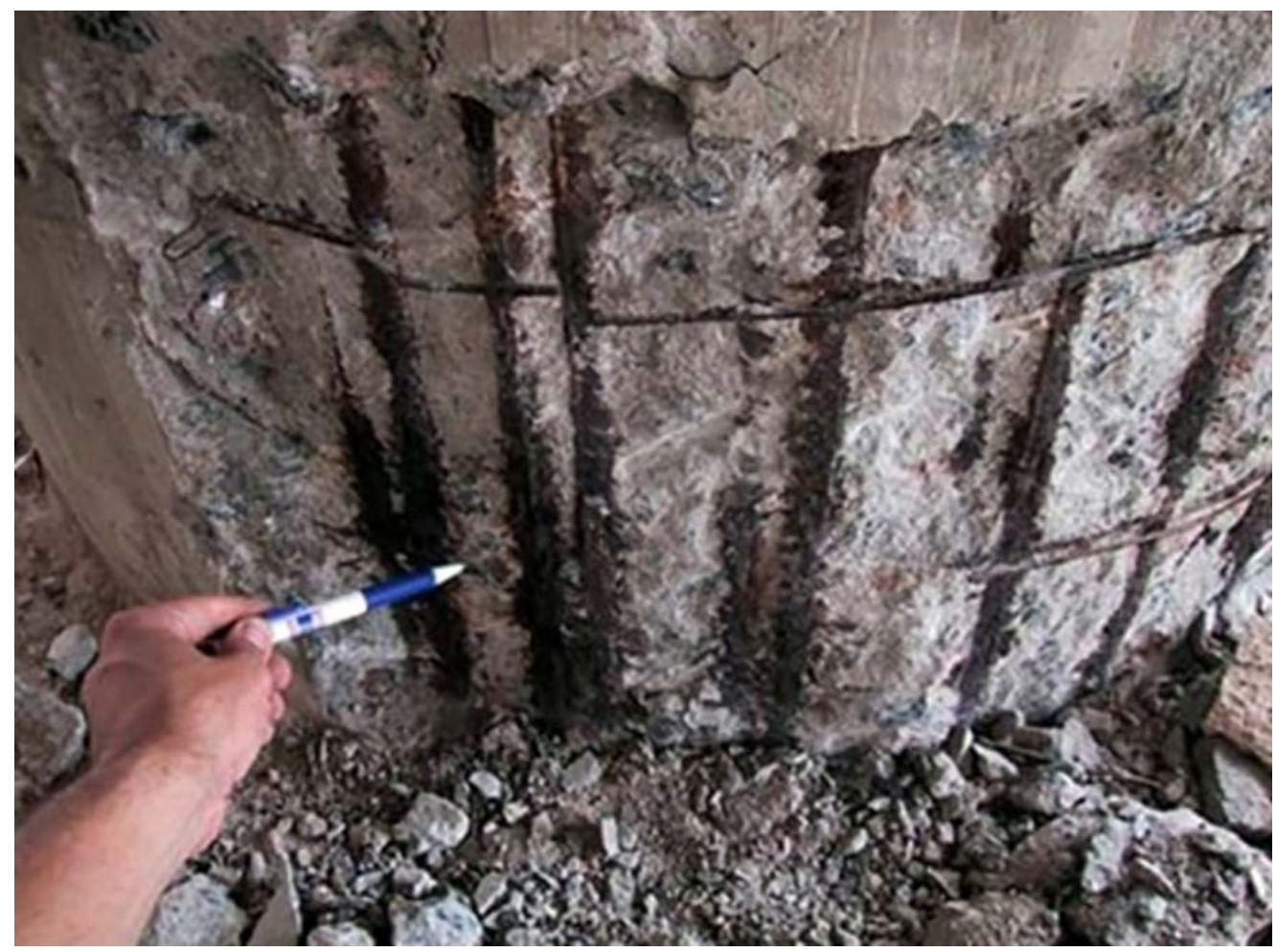

Figure 1. Chemical corrosion of cement stone. 
The process of destruction itself is also ambiguous. G. Hegerman [16], for example, divides it into three periods:

I period - decomposition of calcium hydroxide and decomposition of the smallest particles of clinker; $\mathrm{Ca}(\mathrm{OH})_{2}$;

II period - coagulation of the formed gels $\mathrm{Al}(\mathrm{OH})_{3}$ and $(\mathrm{OH})_{4}$ and partial adsorption of

III period - cessation of leaching of calcium oxide and enveloping the products of neoplasms with a film of silica gels.

According to Werner, the decomposition process is divided into 2 periods:

The first - is a short one, during which free calcium hydroxide rapidly decomposes;

The second - is a long period of hydrolysis of hydrosilicates and calcium hydroaluminates [14].

The general opinion of researchers is that the resistance of concrete to type 2 corrosion is determined by the density (impermeability) of the concrete and the content of unbound calcium hydroxide.

Naturally, its density plays an extremely important role in the resistance of concrete to chemical corrosion. The larger the surface area of contact between concrete and an aggressive medium and the filtration of water through concrete, the greater the rate of corrosion development.

But it would be wrong to assume that only density determines the resistance of concrete to chemical corrosion.

The rate and sequence of destruction of concrete under conditions of development of corrosion processes of the 2 nd type is influenced by the mineral composition of cement clinker, the material composition of cement (content of mineral additives), as well as the structure of cement stone and concrete [4].

The resistance of concretes on various cements to chemical corrosion has been compared by many researchers $[4,14,19]$. The data of various authors on the leaching of lime from pozzolanic Portland cements convincingly prove the constructive role of active mineral additives. These additives not only change the chemical composition of the cement stone, but also reduce its permeability. It is proved that the corrosion process in concretes on slag Portland cements proceeds, all other things being equal, much slower than concretes on Portland cements. There is an increased durability of concretes based on alumina cements.

As for the studies of the relationship between the resistance of concrete to chemical corrosion and the characteristics of the structure, there are frankly few of them.

It has already been mentioned about the assessment of the role of the density of concrete, and hence their porosity, in the development of corrosion of the $2^{\text {nd }}$ kind.

As an important negative structural factor, the introduced by F.M. Ivanov, an indicator of the development of corrosion is the degree of chemical degeneration of the cement stone. By the way, the available data show that after removing $10 \%$ of the lime (based on the original cement), the strength of concrete decreases rapidly, and its condition should be considered unstable. This critical value of the volume of the modified cement stone should be borne in mind when calculating the resistance values of concrete. should be borne in mind when calculating concrete resistance indicators.

Given the limited information on the effect of the characteristics of the structure of concrete on its chemical resistance, studies of this type of concrete corrosion are of particular interest. 
Let us recall that the regularity of the increase in the resistance coefficient of concrete (according to V.V. Kind) with an increase in the volume of cement stone has been established "Figure 2".

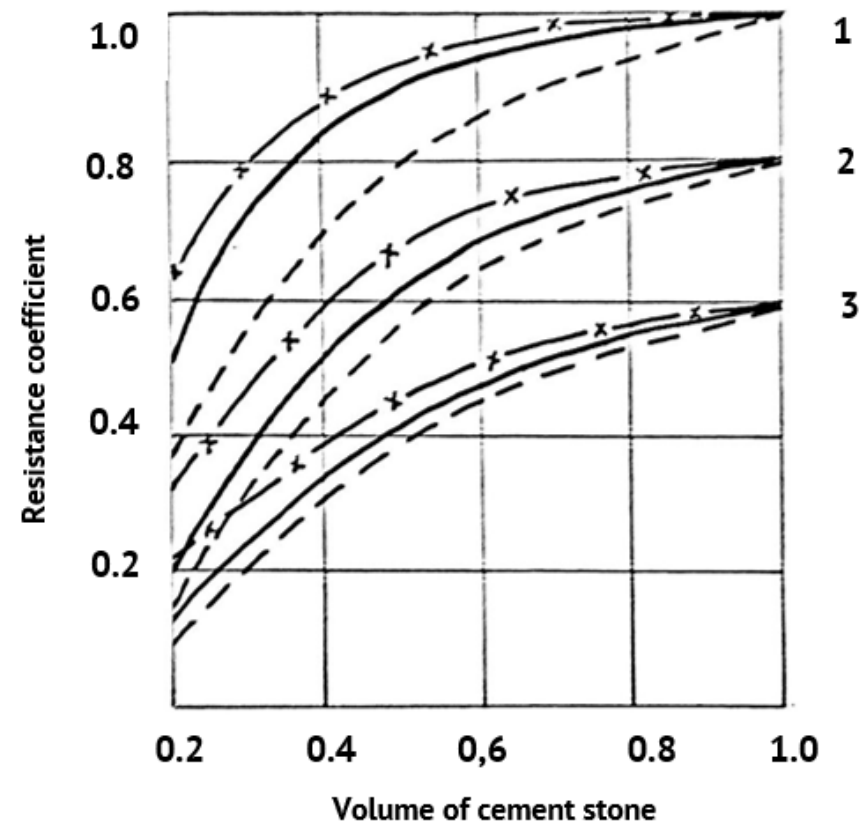
1) $W=0.24$
2) $\mathrm{W}=0.34$
3) $W=0.44$

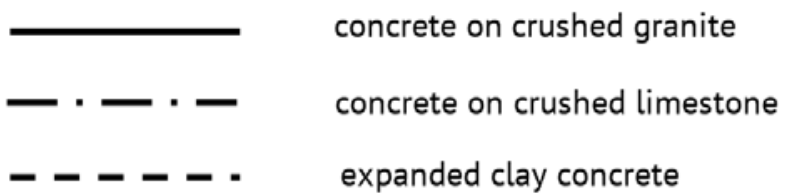

Figure 2. Dependence of the coefficient of resistance of concrete to chemical corrosion on the volume of cement stone.

For all the seeming prosaicity, this is a very curious and remarkable fact, according to which the resistance of concrete does not depend on the content of calcium hydroxide in it. The unambiguous relationship between the resistance coefficient and the volume of communicating porosity has been confirmed. The important role in the development of corrosion processes of the contact zone between the cement stone and the aggregate has been revealed. The best resistance to this type of corrosion has been proven for carbonate concretes, which have a higher quality (in comparison with concretes on granite) contact zone.

The reduced resistance of expanded clay concrete is noted due to their high water absorption. It was found that "reserve" porosity does not play a significant role in the development of corrosion. Based on the above and taking into account the formula for the generalized structural parameter of resistance, the structural parameter of resistance to chemical corrosion can be expressed by the following relationship "Eq.(2)":

$$
P_{c r}=\left(C-P_{\text {total }}-C_{\text {mod }}\right) / P_{1 c}+P_{2 c}
$$

where $P_{c r}$ is a parameter of concrete corrosion resistance; $C$ - the volume of the cement stone; $P_{\text {total }}$ - total porosity of concrete; $P_{1 c}$ and $P_{2 c}$ - respectively, the porosity of the 1 st and 2 nd groups, determined by the three-stage saturation method; $C_{\bmod }$ - the volume of the modified 
cement stone. From a physical point of view, this parameter is the volume of cement stone that can be destroyed at a given aggressiveness of the environment (such as an aggressive agent, time and operating conditions). It is determined by calculation, depending on the mineralogical composition of the cement, taking into account the peculiarities of the corrosion process. More often it is equal to the volume of calcium hydroxide contained in concrete.

In the denominator of the parameter, as destructive, are the pore volumes of the 1st and 2 nd groups of cement stone and porous aggregate, since an aggressive medium enters the concrete through them. The volume of these pores largely determines the permeability of concrete. The composition of the pores of the 1st and 2 nd groups entirely includes the porosity of the contact zone between the cement stone and the aggregate, which is the main way of filtering moisture through concrete.

According to the criterion dependence, it is assumed that $\left(C-P_{\text {total }}-C_{\text {mod }}\right)$, the preserved dense frame of the cement stone, that is, the constructive volume, which determines the bearing capacity of concrete after corrosion.

Thus, the physical meaning of the structural parameter means the density of the placement of defects in the cement stone untouched by corrosion. It fully takes into account the fact that concretes on crushed granite are superior to expanded clay concretes in resistance to chemical corrosion, but inferior to concretes on limestone.

Analysis of the experimental data "Table 1" showed that the structural parameter satisfactorily describes the dependence of the resistance coefficient (according to V.V. Kind) on the characteristics of the structure.

Table 1

Determination of the structural parameter of resistance to chemical corrosion

\begin{tabular}{|c|c|c|c|c|c|c|c|c|}
\hline \multirow{2}{*}{ N/o } & \multirow{2}{*}{$\begin{array}{l}\text { Volume of } \\
\text { cement } \\
\text { stone }\end{array}$} & \multirow{2}{*}{$\begin{array}{c}\text { W / C } \\
\text { cement } \\
\text { stone }\end{array}$} & \multicolumn{3}{|c|}{$\begin{array}{l}\text { Porosity, proportion of } \\
\text { concrete volume }\end{array}$} & \multirow{2}{*}{$\begin{array}{l}\text { The volume of } \\
\text { the modified } \\
\text { cement stone }\end{array}$} & \multirow{2}{*}{$\begin{array}{l}\text { Chemical } \\
\text { corrosion } \\
\text { resistance } \\
\text { parameters }\end{array}$} & \multirow{2}{*}{$\begin{array}{l}\text { Resistance } \\
\text { coefficient }\end{array}$} \\
\hline & & & $p_{1}$ & $p_{2}$ & $P_{\text {total }}$ & & & \\
\hline 1 & 2 & 3 & 4 & 5 & 6 & 7 & 8 & 9 \\
\hline \multicolumn{9}{|c|}{ Concrete on crushed granite } \\
\hline 1 & 0,2 & 0,24 & 0,042 & 0,085 & 0,125 & 0,029 & 0,36 & 0,36 \\
\hline 2 & 0,3 & 0,24 & 0,043 & 0,087 & 0,169 & 0,044 & 0,67 & 0,68 \\
\hline 3 & 0,4 & 0.24 & 0,044 & 0,088 & 0,174 & 0,055 & 1,29 & 0,81 \\
\hline 4 & 0,5 & 0,24 & 0,045 & 0,091 & 0,179 & 0,075 & 1,81 & 0,90 \\
\hline 5 & 0,6 & 0,24 & 0,047 & 0,093 & 0,185 & 0,090 & 2,32 & 0,95 \\
\hline 6 & 0.2 & 0,34 & 0,060 & 0,091 & 0,150 & 0,024 & 0,17 & 0,20 \\
\hline 7 & 0,3 & 0,34 & 0,065 & 0,120 & 0,228 & 0,038 & 0,19 & 0,37 \\
\hline 8 & 0,4 & 0,34 & 0,073 & 0,146 & 0,267 & 0,050 & 0,38 & 0,51 \\
\hline 9 & 0,5 & 0,34 & 0,081 & 0,160 & 0,290 & 0,063 & 0,61 & 0,60 \\
\hline 10 & 0,6 & 0,34 & 0,087 & 0,173 & 0,310 & 0,076 & 0,82 & 0,68 \\
\hline 11 & 0,2 & 0,44 & 0,080 & 0,101 & 0,175 & 0,021 & 0,05 & 0,13 \\
\hline 12 & 0,3 & 0,44 & 0,089 & 0,131 & 0,250 & 0,032 & 0,10 & 0,24 \\
\hline 13 & 0,4 & 0,44 & 0,094 & 0,188 & 0,334 & 0,043 & 0,11 & 0,34 \\
\hline 14 & 0,5 & 0,44 & 0,100 & 0,220 & 0,374 & 0,055 & 0,22 & 0,41 \\
\hline 15 & 0,6 & 0,44 & 0,120 & 0,240 & 0,415 & 0,066 & 0,33 & 0,48 \\
\hline
\end{tabular}


Continuation Table 1

Concrete on crushed limestone

\begin{tabular}{lllllllll}
\hline 16 & 0,3 & 0,24 & 0,047 & 0,093 & 0,138 & 0,044 & 0,84 & 0,75 \\
\hline 17 & 0,4 & 0,24 & 0,050 & 0,097 & 0,154 & 0,055 & 1,30 & 0,87 \\
\hline 18 & 0,5 & 0,24 & 0,051 & 0,098 & 0,164 & 0,075 & 1,85 & 0,94 \\
\hline 19 & 0,6 & 0,24 & 0,052 & 0,100 & 0,174 & 0,090 & 2,41 & 0,97 \\
\hline 20 & 0,2 & 0,34 & 0,063 & 0,102 & 0,147 & 0,024 & 0,18 & 0,30 \\
\hline 21 & 0,3 & 0.34 & 0,072 & 0,135 & 0,209 & 0,038 & 0,26 & 0,46 \\
\hline 22 & 0,4 & 0,34 & 0,080 & 0,160 & 0,242 & 0,050 & 0,47 & 0,57 \\
\hline 23 & 0,5 & 0,34 & 0,083 & 0,165 & 0,271 & 0,063 & 0,67 & 0,66 \\
\hline 24 & 0,6 & 0,34 & 0,090 & 0,175 & 0,293 & 0,076 & 0,89 & 0,73 \\
\hline 25 & 0,2 & 0,44 & 0,085 & 0,138 & 0,169 & 0,021 & 0,09 & 0,25 \\
\hline 26 & 0,3 & 0,44 & 0,094 & 0,178 & 0,237 & 0,032 & 0,11 & 0,33 \\
\hline 27 & 0,3 & 0,24 & 0,047 & 0,093 & 0,138 & 0,044 & 0,84 & 0,75 \\
\hline 28 & 0,4 & 0,44 & 0,103 & 0,205 & 0,326 & 0,043 & 0,12 & 0,40 \\
\hline 29 & 0,5 & 0,44 & 0,111 & 0,232 & 0,368 & 0,055 & 0,23 & 0,47 \\
\hline 30 & 0,6 & 0,44 & 0,125 & 0,257 & 0,408 & 0,066 & 0,34 & 0,52 \\
\hline
\end{tabular}

Expanded clay concrete

\begin{tabular}{lllllllll}
\hline 31 & 0,2 & 0,24 & 0,060 & 0,319 & 0,114 & 0,029 & 0,15 & 0,30 \\
\hline 32 & 0,3 & 0,24 & 0,062 & 0,291 & 0,128 & 0,044 & 0,36 & 0,32 \\
\hline 33 & 0,4 & 0,24 & 0,064 & 0,265 & 0,144 & 0,059 & 0,59 & 0,67 \\
\hline 34 & 0,5 & 0,24 & 0,065 & 0,240 & 0,154 & 0,075 & 0,89 & 0,78 \\
\hline 35 & 0,6 & 0,24 & 0,067 & 0,211 & 0,164 & 0,090 & 1,24 & 0,85 \\
\hline 36 & 0,2 & 0,34 & 0,067 & 0,358 & 0,140 & 0,024 & 0,10 & 0,14 \\
\hline 37 & 0,3 & 0,34 & 0,072 & 0,340 & 0,180 & 0,038 & 0,20 & 0,30 \\
\hline 38 & 0,4 & 0,34 & 0,077 & 0,320 & 0,212 & 0,050 & 0,35 & 0,44 \\
\hline 39 & 0,5 & 0,34 & 0,081 & 0,298 & 0,252 & 0,063 & 0,49 & 0,35 \\
\hline 40 & 0,6 & 0,34 & 0,088 & 0,275 & 0,273 & 0,076 & 0,69 & 0,62 \\
\hline 41 & 0,2 & 0,44 & 0,080 & 0,470 & 0,163 & 0,021 & 0,03 & 0,10 \\
\hline 42 & 0,3 & 0,44 & 0,094 & 0,450 & 0,220 & 0,032 & 0,09 & 0,020 \\
\hline 43 & 0,4 & 0,44 & 0,101 & 0,430 & 0,43 & 0,043 & 0,10 & 0,30 \\
\hline 44 & 0,5 & 0,44 & 0,110 & 0,408 & 0,8 & 0,055 & 0,20 & 0,40 \\
\hline 45 & 0,6 & 0,44 & 0,120 & 0,385 & 0,356 & 0,066 & 0,30 & 0,46 \\
\hline
\end{tabular}

The analytical dependence of the relationship between the value of the structural parameter and the resistance index can be used to predict the resistance of concrete to chemical corrosion "Eq.(3)":

$$
K_{r}=0,61 \cdot P_{l c} 0,57
$$

where $K_{r}$ is the coefficient of resistance; $P_{l c}$ - structural parameter of leaching corrosion.

According to the dependence "Figure 3", concretes with $P_{l c}$ more than $2\left(K_{r}>0.9\right)$ should be considered resistant. This is the value of the parameter for concretes based on pozzolanic and slag Portland cements with a sufficient, of course, density. Concretes based on alumina cement have high parameter values - more than 3 . Concretes with $P_{l c}<2\left(K_{r}<0.8\right)$ should be considered unstable, the volume of hydroxide in them approaches the value of 0.1 , which was noted as critical. However, it should be borne in mind that such parameters can also be present in concretes with active mineral additives, for example, at high W / C (watercement ratio). Thus, the structural parameter can be used with sufficient efficiency to predict the resistance of any type of concrete to type 2 corrosion [20, 21]. 


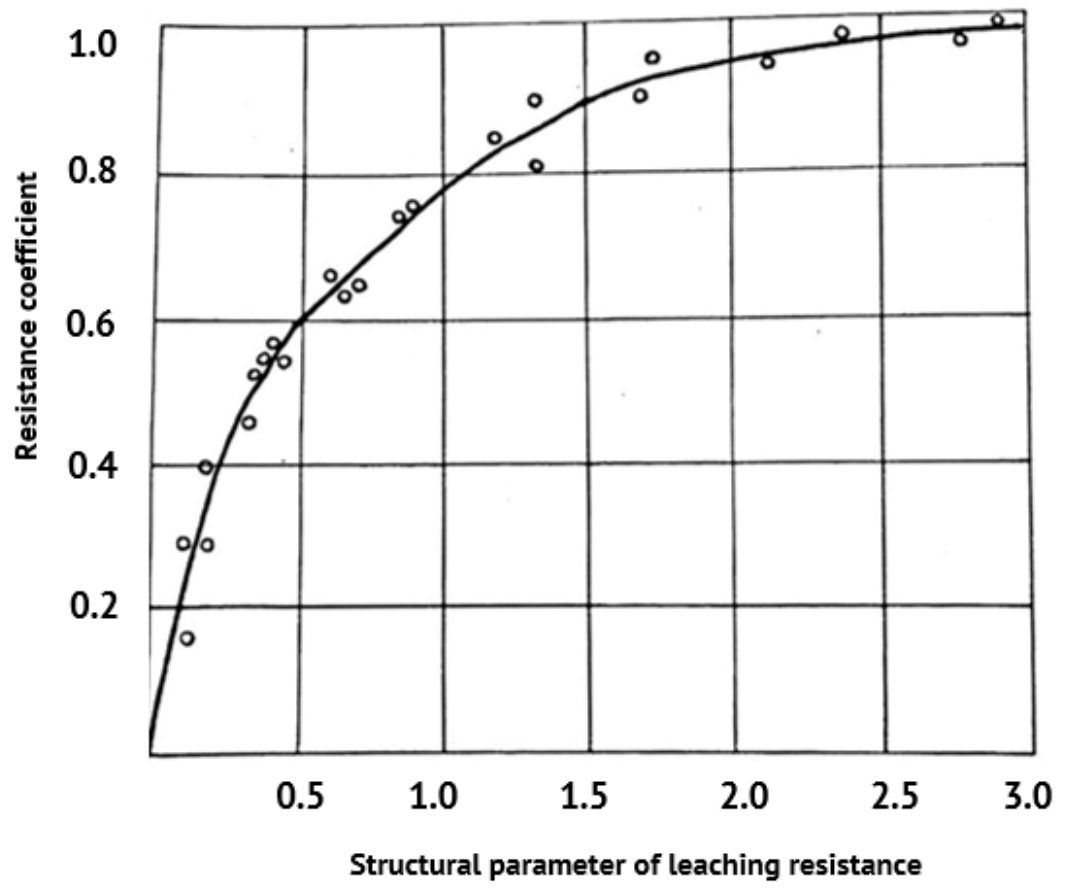

Figure 3. Dependence of the coefficient of concrete resistance to leaching corrosion on the structural parameter.

Obviously, in the course of any processes of chemical corrosion of the 2nd type, the same factors are destructive - the volume of communicating porosity that filters an aggressive medium (porosity of the 1st and 2nd groups). Therefore, the denominator of the structural parameters of the resistance of concrete to chemical corrosion can be the same. The difference in the course of corrosion processes of the second type in the parameter is taken into account by the different volume of the degenerated cement stone - this volume depends on the specifics of one or another type of chemical corrosion. The more aggressive the environment, the less permeable the concrete, the lower the value of the parameter, the lower the corrosion resistance.

An experimental verification of the possibility of using the parameter to assess the resistance of concrete to chemical corrosion has been carried out. The largest selected series of concrete samples on various types of aggregates were tested for the resistance of concrete to the effects of tartaric, lactic and citric acids. A completely reliable relationship between the parameter and the resistance indicators has been confirmed.

\section{Conclusions}

The destruction of cement stone and concrete under the influence of technological solutions of food production occurs mainly as a result of processes caused by chemical corrosion. In essence, chemical corrosion has a certain specificity that must be taken into account when developing an appropriate structural parameter. The durability of concrete does not depend on the content of calcium hydroxide in it. The unambiguous relationship between the resistance coefficient and the volume of communicating porosity has been confirmed. An important role in the development of corrosion processes of the contact zone between the cement stone and the aggregate has been revealed. The best resistance to this type of corrosion has been proven for carbonate concretes, which have a higher quality (in comparison with concretes on granite) contact zone. 


\section{References}

1. Moskvin V.M. Metody issledovania korrozii betona / Korrozia betona $v$ agressivnih sredah [Methods for the study of concrete corrosion / Corrosion of concrete in aggressive environments]. - M.: Stroiyizdat, 1971.

2. Chekhov A.P. Zashchita stroitel'nykh konstruktsiy ot korrozii [Corrosion protection of building structures].- Kiev: Vishcha shkola, 1977.- 216 p.

3. Moskvin V.M., Ivanov F.M., Alekseev S.N., Guzeev E.A.. Korroziya betona i zhelezobetona i metody ikh zashchity [Corrosion of concrete and reinforced concrete and methods of their protection], - M.: Stroyizdat, 1980.-535 p.

4. Lykov A.V. Teoriya sushki [Drying theory], - M. : Gosenergoizdat, 1950, - 201 p.

5. Shestoperov S.B. Dolgovechnost' betona [Durability of concrete], - M.: Publishing house M., 1980, - 345 p.

6. Gorchakov, G.I., Orentlikher, L.P., Lifanov, I.I., Muradov, E.G. Povysheniye treshchinostoykosti $i$ vodostoykosti legkikh betonov dlya ograzhdayushchikh konstruktsiy [Increasing crack resistance and water resistance of lightweight concrete for enclosing structures], - M.: Stroyizdat, 1971

7. Zashchita zhelezobetonnykh rezervuarov ot korrozii/Ninodeliye $i$ vinogradorstvo [Protection of reinforced concrete tanks from corrosion // Winemaking and viticulture]. - M. 1961, no. 7.

8. Timofeev D.P. Kinetika adsorbtsii [Kinetics of adsorption]. - M.: Publishing house of the Academy of Sciences of the USSR, 1962.

9. Tishchenko T.P., Trofimovich A.N. Povysheniye dolgovechnosti stroitel'nykh konstruktsiy pishchevykh predpriyatiy [Increasing the durability of building structures for food enterprises // Food industry].-1983.№4.

10. Turkestanov G.A. Issledovaniye poristosti betona metodom vodopogloshcheniya [Investigation of concrete porosity by water absorption method].- Scientific and technical report of NIS Gidroproekt, 1959-1960, p. 237.

11. Yu.D. Zolotukhin, S.G. Vasiliev Povysheniye dolgovechnosti stroitel'nykh konstruktsiy, rabotayushchikh $v$ agressivnykh sredakh konditerskikh proizvodst / Effektivnyye metody zashchity ot korrozii [Improving the durability of building structures operating in aggressive environments of confectionery industries / Effective methods of protection against corrosion]: Abstracts of the conference. - Kishinev, 1979, p. 3-5.

12. Kishitani K, - Zement - Kalk - Gips, 1964, nr. 4. p. 24-26.

13.Jung V.N. Osnovy tekhnologii vyazhushchikh veshchestv [Basics of technology of binders]. - M .: Stroyizdat, 1951.

14. Moskvin V.M. Korroziya betona [Corrosion of concrete]. - M .: Gosstroyizdat, 1952.

15. Baykov A.A. O deystvii morskoy vody na sooruzheniya iz gidrotekhnicheskikh rastvorov [On the effect of sea water on structures from hydraulic solutions].- Collection of works, T.U.-M., L., 1948.

16. Engineering News Record. - 1946, v. 137, nr. 16

17. A. A. Mechai, O. E. Khotyanovich, A. A. Sakovich. Gidroliz i tverdeniye mineral'nykh vyazhushchikh veshchestv [Hydrolysis and hardening of mineral binders], manual for students, Minsk: BSTU, 2012. - 72 p. ISBN 978 985-530-203-3.

18. Rumyantsev P.F., Khotimchenko V.S., Nikushenko V.M. Gidratatsiya alyuminatov kal'tsiya [Hydration of calcium aluminates]. - L., 1974.

19. Kind V.V. Korroziya tsementov $i$ betona $v$ gidrotekhnicheskikh sooruzheniyakh [Corrosion of cements and concrete in hydraulic structures]. - M., L.; Gosenergoizdat, 1955.

20.https://studopedia.info/1-60516.html

21.https://tse.expert/info-block/opinions/korroziya-tsementnogo-kamnya/ 